\title{
WHAT MAKES THE SECURITIES CRIMINAL LAW SYSTEM OF THE UNITED STATES WORK? 'ALL-EMBRACING' 'BLANKET' SECURITIES CRIMES AND THE LINKED ENFORCEMENT FRAMEWORK
}

\begin{abstract}
Perhaps this article will stimulate the interest of some of the unfamiliar, provoke dialogue and constructive criticism from the skeptical, or provide some guidance for the burdened practitioner or public servant. If, at a minimum, it whets the appetite of the reader and thereby raises the question in his mind whether this area of legal endeavor merits further exploration, it shall have accomplished its purpose. ${ }^{1}$
\end{abstract}

\begin{abstract}
The article explores the key factors that make the securities criminal law of the United States (US), as one of the integral building blocks of the capital markets and securities regulatory system, efficient. This includes the role and characteristics of sectoral (blanket) all-embracing securities crimes enshrined into the federal securities statutes, their nexus with general crimes, the close cooperation of the Securities Exchange Commission (SEC) and prosecutorial offices, the applicable
\end{abstract}

Professor of Law, Department of Legal Studies, Central European University-Private University, Vienna, Austria; e-mail: tajtit@ceu.edu. The author would like to express his gratitude for the exchanges related to the topics covered in this article to Kathy Bazoian Phelps and Greg Bartalos as well as to Prof. Károly Bárd (CEU-PU Vienna, Austria), Prof. Csongor István Nagy (Szeged Law School, Hungary), and Prof. Slobodan Vukadinović (UNION, Belgrade, Serbia). My gratitude goes to Kerstin Pilt (now with Swedbank-Estonia, Head of Compliance, and more than ten years ago with the Estonian Financial Supervisory and Resolution Authority) related to the exchanges on the development of the Estonian financial system in the post-1990 period.

1 Mathews A. F., 1971, Criminal prosecutions under the federal securities laws and related statutes: The nature and development of sec criminal cases, George Washington Law Review, Vol. 39, No. 5, p. 903. Arthur F. Mathews was in the 1960s the Deputy Associate Director of the Division of Trading and Markets at the Securities and Exchange Commission, and for several years was in charge of the Office of Criminal Reference and Special Proceedings. He seems to be little known outside the US though he published a series of articles, successfully combining the theoretical and practical aspects of criminal enforcement of securities laws. 
evidentiary standards, and the fundamental policies undergirding these laws. The rich repository of US experiences should be instructive not only to the Member States of the European Union (EU) striving to forge deeper capital markets but also to those endeavoring to accede the EU (e.g., Serbia), or to create deep capital markets for which efficient prosecution of securities crimes is inevitable.

Key words: capital markets, blanket-, all-embracing securities crimes, proving mens rea, circumstantial evidence, nulla crimen sine lege.

\section{Introduction: Why Focus on Securities Crimes?}

\subsection{THE PERSPECTIVE OF EUROPEAN EMERGING FINANCIAL REGULATORY SYSTEMS}

For those European jurisdictions still being outside the EU, taking over of the acquis communautaire with its securities laws remains both a priority and a daunting task. That the transposition has been arduous could readily be inferred from the fact that the outcomes often remain limited to formal addition of a few securities crimes to local criminal codes, or sectoral statutes; to wit, to 'ticking the boxes.' Unfortunately, simple formulas do not exist for making the system produce results. Even the mandate of making EU law part of domestic legal systems is perceived as a predominantly formal task, which itself is paralleled by numerous dilemmas from finding the right place of securities crimes in the legal system, determining their proper qualification (felonies v. misdemeanors), ${ }^{2}$ hardships caused by frequent amendments of laws, to 'hyper-criminalization.' ${ }^{3}$ Some tentative conclusions have already seen the daylight though. Placement of securities crimes in sectoral statutes, at least as Serbian experiences

2 Croatia, for example, had had a separate statute enacted in 2009 titled Act on Crimes against Capital Markets (Zakon o kaznenim djelima protiv tržišta kapitala, Narodne novine, No. 152-08, 2008), which was thereafter abolished by the new Criminal Law of 2013. Securities crimes were placed in the chapter on crimes against the economy. Although some of these crimes were 'degraded' into misdemeanors, generally the imposable penalties became stricter over time. A sub-statutory level Rule on Manipulation and on the Duty to Report Suspicious Abuses on the Market were promulgated by the Croatian SEC as well in 2009 but no empirical evidences are available on its practical utility. See Kaleb, Z., 2014, Kaznena djela protiv tržišta kapitala i vrijednosnih papira prema novome kaznenom zakonu [Crimes against Capital- and Securities Markets According to the New Criminal Act], Policija i sigurnost, Vol. 23, No. 1, pp. 82-89.

3 Kostić, J., Trošić, S. J., (In)adequate criminal protection of the capital market in the Republic of Serbia, in: Petrašević, T., Duić, D. (eds.), 2020, Eclic 4, EU and Comparative Law Issues and Challenges, International Scientific Conference EU 2020 - Lessons from the past and solutions for the future, Osijek, September 10-11, 2020 (Publ. Josip Juraj Strossmayer Law School, Osijek, Croatia), p. 615. 
suggest, ${ }^{4}$ seem to be the formula for failure as they have hardly been applied. ${ }^{5}$ At least, if Serbian statistical reports are departed from, which do not contain distinct rubrics specifically for securities crimes. ${ }^{6}$

The modest number of agency and court cases in the domain (if any), and the dearth of industrial and scholarly publications, either in English or in local languages, do prove the above, even if indirectly. To certain extent understandably, courses devoted to the field are lacking from the curricula of law schools, given the fledgling capital markets, scarcity of jobs requiring specialization to the field, and lack of quality teaching materials. It should not come as a surprise then that normally there is little interest for study of US securities laws either, irrespective that EU law is increasingly influenced by it in the securities domain ${ }^{7}$ and unquestionably the US possesses the most tested and multi-faceted securities regulatory system in the world today. Indeed, no matter which specific types of securities crimes are at stake - from insider trading, manipulation, to Ponzi schemes - the sheer number of successfully prosecuted cases in the US clearly surpasses those of Europe; as showed by available quantitative data. ${ }^{8}$

4 For a detailed overview of Serbian securities crimes laws (or secondary criminal legislation) see Kostić, J., Trošić, S. J., 2020, pp. 606-612. The Serbian blanket securities crimes are in the Law on the Capital Market (Official Gazette of RS, No 31/2011, $112 / 2015,108 / 2016$ and 9/2020), the Law on Takeovers of Joint Stock Companies (Official Gazette of RS, Nos. 46/2006, 107/2009, 99/2011 and 108/2016) and the Law on Open-Ended Investment Funds subject to Public Offering (Official Gazette of RS, No. 73/2019). Ibid.

5 Turanjanin, V., 2017, Privredna krivična dela iz sporednog krivičnog zakonodavstva [Economic Crimes in Blanket Crimes Statutes] in: Stevanović, I., Čotović, V., Privredna krivična dela, Belgrade, Institut za uporedno pravo - Institut za kriminološka i sociološka istraživanja, abstract, p. 203. Kostić and Trošić expressed this more subtly claiming that "some of the legal systems are not mature enough" for combating securities crimes by way of blanket dispositions. Kostić, J., Trošić, S. J., 2020, p. 615.

6 In Serbia concretely, securities crimes are subsumed under the catch-all, residual statistical category of 'offenses prescribed by other laws.' Kostić, J., Trošić, S. J., 2020, p. 615.

7 See also Kostić, J., 2018, Izazovi harmonizacije krivičnopravne zaštite tržišta kapitala sa pravom evropske unije - Primer italijanskog zakonodavstva [The Challenges of the Harmonization of Penal Protection of Capital Markets According with the Law of the European Union - The Case of Italian Law], Strani pravni život, Vol. 62, No. 2, pp. 119-139.

8 For some specific types of securities crimes, well-developed databases do exist in the US. For example, for data and concrete figures on the number of initiated criminal cases and criminal penalties imposed for organization and operation of Ponzi schemes see Ponzitracker (https://www.ponzitracker.com) run by Jordan Maglich, and the blog with monthly recaps of Ponzi scheme discoveries and news run by Kathy Bazoian Phelps (www.theponzibook.com). 


\subsection{WHAT TO EXPECT FROM THE LAW OF THE EUROPEAN UNION ${ }^{9}$}

Irrespective of the high priority attributed to the development of deep capital markets by the EU, Europe is continuedly incapable of bringing about a major volte face in the domain, be it boosting equity financing of large corporates (let alone small and mid-scale enterprises), ${ }^{10}$ or making major advancements in prosecuting securities crimes notwithstanding that the underlying legislation has been in place for years. ${ }^{11}$ The pertaining discourse has remained dominated by rhetorical rather than pragmatic considerations as well. The quest for the formulas that could give teeth to written laws, therefore, has been given less attention to, and the related processes have hardly reached their satisfactory ending either. Irrespective of that, the study of US laws and experiences, as the richest repository of adaptable answers, has hardly become routine in Europe.

A sectoral tug-of-war about a number of fundamental systemic and policy issues has been also occurring in Europe. This is the conflict between the old, the 'inherited frameworks', and the desirable improvements of the system driven by the fast-changing environment, failures as well as regulatory competition. The aspirations of Brussels notwithstanding, effectuating changes is hard not only because of the radically different stature of the Member States' capital markets and the linked industries, but also because of their differing-intensity political resistance. Hence, many of the EU's efforts have actually ended up as flatus voci in the domain, as it was so with the pledge of EU and the US to converge their securities regulations, driven by such recent disasters with myriad spillover effects as the 2007 Credit Crunch and the ensuing global financial crisis.

Consequently, today, as commentators claim, all the recent-vintage European pieces of legislation continuedly "fail to fundamentally alter the

9 See in particular Communication from the Commission to the European Parliament, the European Council, the Council, the European Central Bank, the European Economic and Social Committee and the Committee of the Regions Capital Markets Union: Progress on Building a Single Market for Capital for a Strong Economic and Monetary Union (Brussels, 15 March 2019). As stated in this document: “The Capital Markets Union is also an important Single Market project. It will increase firms' and citizens' access to capital markets - especially in smaller countries - by making links between their local capital market ecosystems and deeper pools of capital across the EU. By diversifying sources of finance for EU's businesses, the Capital Markets Union can support investment in innovation and technological developments, thereby promoting the EU's global competitiveness."

10 See, e.g., Morrissey, D. J., 2019, The EU's Struggles with Collective Action for Securities Fraud: An American Perspective, Texas A\&M Law Review, Vol. 7, No, 1, p. 130 et seq.

11 Reference is made, in particular, to the Market Abuse Regulation 569/2014 (L 173/1). 
current overreliance on disclosure [and fail to] agree on common liability standards which can disincentivize overly risky behavior." ${ }^{12}$ They are still based on the "popular assumption that securities regulation operates against the backdrop of stable market gatekeepers, like exchanges, broker-dealers, and clearing-systems [yet which is] a fact scenario increasingly out of sync in twenty-first century capital markets." 13 Whether these facts ought to be perceived merely as indicators that securities regulations are exposed to constant pressure for adjustments and upgrading due to the extremely dynamic nature of the markets, or rather as factors that are doomed to elevate the importance also of the criminal justice system in protecting the integrity of capital markets and of investors any time soon, remains to be seen.

The dilemmas notwithstanding, the above briefly canvassed characteristics of contemporary EU are realities that should be heeded not only by the Member States of the EU, but by the aspiring countries standing in the accession doors of this supranational organization. Put pithily, the limitations of EU law is a factor that should matter to realistically assess of what researchers, reformers or practitioners could expect from it.

\subsection{WHAT CAN THE RESEARCHER EXPECT FROM GERMAN AND UK LAWS IN THIS DOMAIN?}

As in this domain EU law operates in conjunction with the laws of the Member States, the study of the latter cannot be bypassed. As two financial center of Europe, Germany and the UK might be the best targets for a researcher looking for cases, empirical evidences and analyses. UK remains obviously important notwithstanding Brexit as nothing suggests that any of the Continental European rivals could realistically replace London in the near future.

If insider trading is observed, as that particular type of securities crime the criminalization of which is now a key requirement of EU law, it should be telling that in Germany it had not even been a crime until $1994,{ }^{14}$ when the law changed under pressure coming from Brussels.

12 Brewer, M. K., Gough, O., Shah, N. S., Winter 2011, Reconsidering Disclosure and Liability in the Transatlantic Capital Markets, DePaul Business \& Commercial Law Journal, Vol. 9, No. 2, p. 257.

13 Brummer, C., 2015, Disruptive Technology and Securities Regulation, Fordham Law Review, Vol. 84, No. 3, p. 977.

14 As Dymke and Walter put it: "In Germany, [it is only] since 1994 [that] $\$ 14$ WpHG [Security Trading Act] prohibits the exploitation and transmission of inside information [and] since July 1, 2002 $\$ 15$ a of WpHG requires companies to report corporate insiders' transactions to the public as well as to the regulatory authority, the Bunde- 
Consequently, German law and scholarship might offer very little on the subject yet not only because of the short history of the new regime but also because of the strongly interconnected web of universal banks and the industry.

Perhaps even more surprising is that analogous caveats could be stated also related to UK law, because in the country with the number one financial center of Europe, insider trading was not long ago, not even looked upon as something inherently bad. Rather, significant weight was given to the argument that insider dealing was "a way to compensate corporate personnel, particularly directors, as a mechanism for encouraging innovation." ${ }^{15}$ Similarly to Germany, the criminal offense of insider dealing was introduced only with the Criminal Justice Act $1993 .{ }^{16}$ The radical shift making enforcement of anti-insider dealing laws ${ }^{17}$ with such efficient tools, as unannounced dawn-raids to seize evidences, began also with substantial delay only in $2010 .{ }^{18}$ As this genuinely new era and realignment with American practices is of very recent vintage, UK law comparably still cannot offer as much as the US, where the history of anti-insider trading law goes back to the 1930s New Deal reforms.

\subsection{POST-SOCIALIST SYSTEMS AND THE CONTINUED IMPACT OF THEIR HISTORICAL HERITAGE}

Today, it is commonly subscribed to that transposition of EU law, and generally any transplantation should not be limited to mechanical copying of what the chosen developed models offer. Each recipient country is peculiar in some sense and to some degree, which are factors one has to reckon with. In 2021, it still seems that this applies to the post-socialist CEE countries with heightened force when capital markets and the linked regulations are concerned.

Very expressive examples could easily be found relative to capital markets to back up why this is of major importance. For example, US

sanstalt für Finanzdienstleistungsaufsicht (BaFin).” Dymke, M. B., Walter, A., 2008, Insider Trading in Germany - Do Corporate Insiders Exploit Inside Information? BuR - Business Research Official Open Access Journal of VHB, Vol. 1, No. 2, p. 189.

15 Gullifer, L., Jennifer, P., 2020, Corporate Finance Law - Principles and Policy, Oxford, Hart Publishing, para 12.2., at 604.

16 Ibid, para 12.2.2.1., p. 613.

17 Under English and UK law, 'insider trading' is referred to as 'insider dealing;' the UK nomenclature having been taken over by the EU as well. See Directive 2014/57/EU of the European Parliament and of the Council of 16 April 2014 on criminal sanctions for market abuse (market abuse directive).

18 Burgess, K., Masters, B., 2010, A Bigger Bite, Financial Times, London, UK, 13 May. 
federal securities regulations' strict formula meticulously fixing at which phase, and in what form, may potential investors be approached by issuers of new securities, ${ }^{19}$ could have hardly been directly applied in CEE in the 1990s, or even today. This is so as in this niche of Europe, attracting big banks to serve as underwriters, ${ }^{20}$ without what early-generation issues of securities would have been doomed to failure, presumed lots of preliminary discussions, persuasions, and negotiations. The liberty to do that has been such sine qua non requirement for many years after the fall of the Berlin Wall, ${ }^{21}$ which clearly would not be possible had the strict US standards been applied. Similar dilemmas surround the points raised herein on securities crimes and the efforts aimed at making the securities criminal justice system work.

Though, CEE countries (including the Western Balkans) en bloc are idiosyncratic as they have had to restart the process of building their capital markets virtually with tabula rasa due to decades of socialism the first priority of which had been, indeed, annihilation of all the instrumentalities corollary to investments, capital markets and the abolishment of the underlying laws. The beginning of transition towards market economies in the 1990s, on top of that, presumed also contemporaneous modernization and taking over all the latest-generation developments in this sector of the economy, resulting in a dual-track reform process. Moreover, although three-decades have passed in the meantime, the process of realignment with the West, and with the EU, could have hardly been an exponentially growing linear process. The Balkan wars and other regional military conflicts, the 2008 global-, and more local financial crises have all slowed down the advancement. The unique historical circumstances have consequently remained to a non-negligible degree a challenge up until today in this niche of Europe and they obviously have to be reckoned with here when vouching for the study of US experiences.

Study of the laws of developed securities regulatory systems make sense also because the inexperience, especially if coupled with corrupt practices, may be the road towards disasters of unprecedented dimensions.

19 These rules are known as 'gun jumping' or 'conditioning of the market' in the US. The Black's Law Dictionary defines it as: "The act of unlawfully soliciting the public's purchase of securities before the SEC approves a registration statement."

20 Underwriter is "[...] a person or entity, esp. an investment banker, who guarantees the sale of newly issued securities by purchasing all or part of the shares for resale to the public." Quoted from Black's Law Dictionary.

21 This is based on anecdotal evidences from Estonia, where - similarly to most other CEE countries - banks were initially the only potential large investors of first generations of securities issued in the region yet which legitimately doubted the viability of the freshly launched Estonian capital market in the 1990s. 
Suffice to leaf through the growing literature chronicling about various financial fiascos, fraudulent schemes of smaller or gigantic dimensions, and other forms of financial pathology having emerged exactly in fledgling markets. ${ }^{22}$ The sad truth is that financial fraud tends to surface in emerging markets first, much earlier than a properly functioning stock or commodities exchange. Hard to prove yet the lack of a properly functioning securities crimes enforcement system undoubtedly is one of those crucial factors that could be blamed for that.

\subsection{THE NON-VOLITIONAL DETERMINANTS: ONLINE AND NEW TECHNOLOGIES-BASED FINANCIAL INNOVATION AND SCAMS}

It is not only the desire to accede to the EU, nor the policy goal of building a robust securities regulatory system, and through that also deep capital markets, that makes profitable the study of US law on securities crimes. Besides these volitional aspects, justification should increasingly be found in the risks lurking on all desiring to exploit the ever-newer forms of financial innovation, in particular, technologies-based financial products. The world of finance is presumably the most exposed sector of the economy to the garden variety of concomitant threats, many of which in fact are financial "scams" offered through the Internet, or by other technological means. Examples abound: crypto-assets being the latest-generation species worth mention the emergence of which was made possible thanks to the underlying Blockchain technology.

Globalization, the concomitant ever-stronger interdependence of markets, regulatory competition, as well as intensifying cross-fertilization of laws have just further exacerbated the exposure of all having joined the online sphere. As a result, even the least developed economies of the globe can today both benefit from what the Internet and new technologies

22 The entire governmental system crumbled in Albania in 1997, with about 2,000 lives lost, triggered by the collapse of more than ten shadow banks operating as pyramid schemes. See Jarvis, C., 2002, The Rise and Fall of the Pyramid Schemes in Albania, 47.1 IMF, Washington, D. C. For more concrete cases from around the globe see Tajti, T., 2019, Pyramid and Ponzi Schemes and the Price of Inadequate Regulatory Responses: A Comparative Account of the Diverging Regulatory Responses, Business \& Bankruptcy Law Journal, Vol. 5, p. 19; and Tajti, T., Are Some Classes of Consumer-Investors of Collapsed Pyramid and Ponzi Schemes Vulnerable? in: Stănescu, C-G., Gikay, A.A. (eds.), 2021, Discrimination, Vulnerable Consumers and Financial Inclusion - Fair Access to Financial Services and the Law, pp. 236-288. The leading US textbooks on the subject matter are Frankel, T., 2012, The Ponzi Scheme Puzzle: A History and Analysis of Con Artists and Victims, Oxford University Press, and Bazoian, Ph. K., 2012, The Ponzi Book: Unraveling Ponzi Schemes, New York, LexisNexis. 
offer, and parallel with that become exposed to all the concomitant risks. Emerging systems are in this new environment virtually forced to fundamentally rethink what finance really means. What was yesterday an unwittingly subscribed to axiom, might overnight become questioned. Suitable examples abound, from the continued validity of such fundamental presumptions that commercial banks are the alpha and omega of finance, the sole sources of financing, and the irreplaceable providers of all financial services, ${ }^{23}$ in the light of new market participants appearing thanks to the Internet. Paradigm examples are the Norwegian Norfund, ${ }^{24}$ the Norges Investment Bank oil fund, ${ }^{25}$ and various private equity firms setting foot in Africa or China. ${ }^{26}$

Technology, however, may and is exploited for fraudulent purposes as well. These may be particularly detrimental for countries not possessing a developed securities regulatory system, the necessary legal 'software.' The correlation is that the less developed the regulatory system of a country is, the more vulnerable its markets and its investors are. These perils otherwise are inescapable, and the moment a country joins the online world, it is inevitably exposed to all the endemic risks as well. No better examples could be found than the online versions of Ponzi schemes, which had already left their imprint in the "ether" of countries that not a long ago thought to be fully immune from them. ${ }^{27}$

For sure, as all these technology-linked developments are not only new but are also fast-mutating, the big question is whether combating them perusing securities criminal law developed to fit the realities of the

23 One strand in financial and legal literature promotes the claim that "there is some evidence that countries with an active stock market experience more rapid economic growth". Coffee, J. C. Jr., Sale, H. A., 2009, Securities Regulation, New York, Foundation Press, p. 8. Creating a viable stock exchange, however, is far from being easy; as amply illustrated by empirical evidences not only from the post-socialist countries of Central and Eastern Europe (CEE) but also from examples from other continents. On the topic see Coffee, J. C. Jr., 1999, Privatization and Corporate Governance: The Lessons from Securities Market Failure, Journal of Corporation Law, Vol. 25, No. 1, p. 1, and Brown, J. R. Jr., 1996, Of Brokers, Banks and the Case for Regulatory Intervention in Russian Securities Markets, Stanford Journal of International Review, Vol. 32, No. 2, p. 185.

24 See the webpage of the fund (https://www.norfund.no/, 6. 3. 2021).

25 See the webpage of the fund (https://www.nbim.no/, 6. 3. 2021).

26 See, for example, the PE firm 'iEurope Private Capital' being active in Hungary and in the neighboring countries, with a mandate of "Investing in privately held small and medium sized enterprises in the CEE region seeking capital for growth and expansion". See the website of the firm (http://ieurope.com/, 6. 3. 2021).

27 The new, online versions of Ponzi schemes got even a new designation: 'postmodern Ponzi schemes.' On these and on a recent internet scam spreading across more countries see Tajti, T., 2021, Victims of Ponzi Schemes, pp. 273-276. 
offline sphere would work? Predictably some of the below-discussed US solutions so far unacceptable elsewhere, would soon become a necessity, if not part of normalcy; the paradigm example being New York's revamped standards of proof.

\section{Understanding the Us Federal Securities Regulatory System: General Considerations}

\subsection{A WORD ON THE DISTINCTIVE FEATURES OF US FEDERAL SECURITIES LAW}

Before embarking on the analysis of the law on securities crimes, three reminders should be canvassed briefly about the distinctive nature of this branch of law in the US. The first is that the discipline named as 'securities law,' 'securities regulations', or 'capital markets and securities regulations,' still being based on the New Deal federal securities statutes, ${ }^{28}$ is of hybrid nature because "their prohibitions are enforceable in criminal actions as well as in private or governmental civil actions (or both)." ${ }^{29}$ Figuratively speaking, similarly to a mosaic, it is a discipline composed of such varying building blocks that are actually adapted toolboxes of other (traditional) branches of law: administrative, sector-specific tort-, and criminal laws forming the backbones of the system, as supplemented by contract and company laws.

US sources typically speak of a 'dual-remedy' discipline referring to two sides, the civil and criminal law aspects, of the 'coin'; the 'civil' prong encompassing both the private and administrative law aspects of the discipline as conceived in Europe. It might be novel to European lawyers as well that 'securities law' as perceived in the US is not strictly limited to substantive law but it smoothly extends also onto the procedural facets of the trio. Consequently, perhaps the more suitable reference would be multi-remedial law: a sort of synergic system that exploits all the utilizable legal tools of those areas of law the remedies of which were found to be exploitable.

28 The six core statutes SEC administers are the following: 1/ The Securities Act of 1933; 2/ The Securities Exchange Act of 1934; 3/ The Public Utility Holding Act of 1935;

4/ The Trust Indenture Act of 1939; 5/ The Investment Company Act of 1940; and 6/ The Investment Advisers Act of 1940.

29 The dilemmas surrounding parallel proceedings remain open issues revolving around whether "hybrid statutes can be construed differently in different enforcement contexts." Sachs, M. V., 2001, Harmonizing Civil and Criminal Enforcement of Federal Regulatory Statutes: The Case of the Securities Exchange Act of 1934, University of Illinois Law Review, Vol. 2001, No. 4, p. 1026. 
A corollary of this is that system thinking, in the sense of strict adherence to the established boundaries dividing various branches of law, is incompatible with the US approach because everything serves the ultimate goal of protecting the integrity of the markets and the investors. Theory in this domain is genuinely the servant of practice. This is inevitably reflected also on reasoning of courts, the linked legal scholarship, and therefore also on what follows herein. For those who ponder teaching this subject, the multi-remedial feature of securities laws denotes that more than solid expertise in each of the constituent units is a must; something that could be a major challenge.

Still, the above does not mean that the basic allocation of powers and competences among various state bodies is turned upside down. Most importantly, the SEC, as an independent administrative agency, may only investigate but not criminally prosecute wrongdoers, as explained in more detail below.

\subsection{THE POSTULATES UNDERGIRDING US FEDERAL SECURITIES REGULATIONS}

Three characteristics of capital markets operate as meta-legal postulates that undergird the securities regulatory system of the US: the markets' paramountcy, vulnerability and distinctive nature. These explain not only what justifies the very existence of US securities regulatory systems (federal and State), but also what underlies the embraced policies in the sector. Often the very reasons behind the mechanics of various concrete regulatory techniques employed (e.g., all-embracing blanket securities crimes, to be discussed below) find their explanation in these, too.

Ad paramountcy: that the sector has continuously been attributed utmost regard in the US could readily be seen already from the comparatively large number of securities-related cases granted certiorari to by the US (federal) Supreme Court. This fact in and of itself should be expressive, especially if compared with similar data from other jurisdictions, or other fields of law.

Due regard has always been given by the policy makers and courts as well to the capital markets' vulnerability. Section 2 of the Securities Exchange Act of 1934, titled "Necessity for Regulation as Provided in This Title," for example, directly speaks not only of the fear from another Great Depression, but it also expresses the cognizance that crises "are precipitated, intensified, and prolonged by manipulation" and other forms of fraud. Put pithily, it is the core function of the securities regulations to eliminate fraud from the market not only to protect investors and the integrity of 
the markets in order to maintain trust in the markets and the system, but also to tackle systemic risk and prevent major crises. Obviously, in materializing this central goal, the criminal prong of federal, and State securities laws, cannot but play a central role.

The distinctive nature of capital markets has fully been reckoned with also by all shaping the contours of securities laws from the 1930s on, as the beginning of the modern era, too. As proclaimed by a court in 1949: "the securities field, by its nature, [legitimately] requires specialized and unique legal treatment. ${ }^{30}$ In a sense, it was more the necessities and the peculiarities of the markets than various legal doctrines and theories that impacted securities laws in the US. For example, the recognition that financial innovation incessantly generates ever-newer, or old risks appearing in 'new clothes,' and the possibility of the malicious exploitation of the system's tolerance towards financial innovation by fraudsters, required peculiar solutions as well. To adequately combat these, the drafters of the New Deal securities statutes had forged such sophisticated tools as the economic definition of 'security', thanks to which, if an offering on the market satisfies it, that may immediately trigger the application of any and all of the system's remedies. This definition was intentionally left open to ensure that the coverage of the securities statutes "does not stop with the obvious and commonplace. Novel, uncommon, or irregular devices, whatever they appear to be, are also reached." 31

These considerations are equally relevant to securities criminal law as well, comprehension of the inner logic of which presumes having in sight the above meta-legal determinants. From the many peculiarities specifically of the criminal prong, the extreme hardships with proving intent stand out, similarly to other white collar crimes. This consideration was very expressively stated already in the 1943 case of Archer et al. v. SEC as follows:

The business of trading securities is one in which opportunities for dishonesty are of constant recurrence and ever present. It engages acute, active minds, trained to quick apprehension, decision and action. The Congress has seen fit to regulate this business. Though such regulation must be done in strict subordination to constitutional and lawful safeguards of individual rights, it is to be enforced notwithstanding that the frauds to be suppressed may take on more subtle and involved forms than those in which dishonesty manifests itself in cruder and less specialized activities. [...]. ${ }^{32}$

30 Quoted from the 1949 case Hughes v. SEC 174 F.2d 969.

31 SEC v. C.M. Joiner Leasing Corporation 320 U.S. 344 (1943).

32 Archer et al. v. SEC (1943), p. 803. 
Let us turn now to the technical aspects of our subject matter to be discussed hereinafter focused on the 1934 Securities Exchange Act; ${ }^{33}$ as the most comprehensive of the federal securities statutes that could serve also as the central model resting on similar grounds as the remainder of the New Deal securities pieces of legislation.

\subsection{ON THE RELATIVE POSITION OF SECURITIES CRIMINAL LAWS IN THE HYBRID FEDERAL SECURITIES STATUTES}

That the criminal prong of the securities regulatory system plays a pivotal role in the hybrid toolbox of legal paraphernalia US securities regulations exploit may not be readily visible from text- and casebooks used in the teaching process because these rather focus on the administrative and private law aspects of the discipline. The law against insider trading, for example, is such a mixture in the US, ${ }^{34}$ where the criminal aspects might be overshadowed by the narrative on sector-specific tort law, SEC's omnipotent Rule 10b-5, and private securities litigation; or private enforcement of securities laws. More of the key US federal insider trading cases, however, are criminal cases. ${ }^{35}$ Criminal law, figuratively speaking, is

33 The Securities Exchange Act of 1934, codified at 15 U.S.C. $\$ 78 \mathrm{ff}$, focused on secondary markets, will be relied on here as being the most comprehensive and most important of the federal securities statutes with its penalty Section 32(a). It is suitable to serve as such because the 1933 Securities Act, covering issuance of new securities (or the primary market) only, contains an almost identical section with that in the 1934 Act in its Section 24. The criminal provisions of the Investment Companies Act of 1940 and the Investment Advisers Act of 1940 were patterned after the 1933 and 1934 Acts as well. Mathews, A. F., 1971, p. 1258.

34 This is in stark contrast with UK law, where "there is no civil remedy for market abuse and the enforcement of insider dealing and market manipulation has been left to the public authorities." Gullifer, L., Payne, J. 2011, Corporate Finance Law - Principles and Policy, Hart-Oxford, para 10.5.2., p. 511. No change has been introduced in that respect until 2021. See the $3^{\text {rd }}$ edition of the book para 12.2.1.1.2., p. 607.

35 The criminal cases that are reproduced and commented upon in US text- and casebooks used for teaching insider trading law, decided by the US (federal) Supreme Court, are the following. The first is the 1980 case of Chiarella v. United States (445 U.S. 222, 100 S.Ct. 1108, 63 L.Ed.2d 348) that gave birth to the so-called 'classical theory of insider trading, in which a blue-collar worker, a printer employed by a New York-based financial printer company, was convicted by lower level courts, and eventually acquitted by the Supreme Court. Another major milestone case was the 1997 United States v. O'Hagan (521 U.S. 642, 117 S.Ct. 2199, 138 L.Ed.2d 724), in which the birth of the other key insider trading theory - the misappropriation theory - is rooted.

The third routinely reproduced case of Dirks v. SEC (463 U.S. 646, 103 S.C. 3255, 77 L.Ed.2d 911), important for the refinement of the insider trading theories and yet dealing with temporary insiders, temporary tippers and tippees, was an administrative case in which SEC censured Dirks, a former New York broker-dealer, who exposed fraud of one of his past clients. 
a kind of éminence grise in this context: a seldom spoken of yet inevitable building block of the system.

Ironically, if the relative importance of criminal law in securities context is analyzed in the laws of Continental European systems, normally it is exactly this branch of law that in theory plays "the central role." Such rhetoric, however, is usually contradicted by the low number of reported (and traceable unreported) cases. The misconception might be due to the fact that the peculiar American legal tools - in particular, sector-specific tort law, class actions and the impressive number of remedies available to the SEC - typically, either do not exist, or are not exploited as forcefully as in the US. Yet the number of annually launched criminal cases in the domain, let alone the proceedings ending with penal punishments being imposed and implemented, as a rule is low compared to the US, notwithstanding that the language of the provisions of both EU and those of the Member State laws often are very similar those in the US. Therefore, additional factors, subtler in nature, ought to explain the efficiency of criminal prosecution of securities crimes in the US besides the statutory tests of securities crimes. The ensuing is an attempt to cast a light on the most important ones.

\section{Expansion of Securities Criminal Laws: ReAsons AND TeACHNiques}

\subsection{THE MAIN REASONS BEHIND EXPANSION}

More factors should be listed as reasons behind expansion of federal securities criminal laws in the US. Some are known elsewhere as well, some others, however, are idiosyncratic to the US.

As already concluded, first, capital markets are not only rapidly-changing but may also be exposed to such systemic risks that might shake even the foundations of the entire economic system. Capital markets, additionally, are significantly different from other sectors of the economy. These reasons require delegation of the task of filling the body of securities crimes with contents to governmental agencies not only possessing utmost sectoral expertise but which are also entrusted with the implementation of sectoral laws.

In the US, this is primarily the SEC, and the New Deal era securities regulations. In Europe, at least, in those systems that have been influenced by German criminal law doctrines, these laws are known as 'blanket criminal statutes,' and the crimes placed in these pieces of legislation other than criminal codes, are referred to as 'blanket crimes' (to be discussed in more detail below). Interestingly, although all the core US federal securities acts 
are of that nature, this pair of designations is basically unknown in the US. In the US, the securities blanket crimes coupled with the SEC's entitlement to interpret and fill these with contents is an important avenue whereby the expansion has been occurring with fluctuating intensity since 1934, when SEC was established by the 1934 Securities Exchange Act.

Second, if the premise on the constant alteration of the forms and contents of criminal behavior on the securities markets is accepted, then it is justified to accept also that fraud and other wrongdoings in this domain cannot be put into the straightjacket of a single, or a few, closed-end definitions of securities crimes. Figuratively speaking, running back to the legislator every time a new product, or new scam, appears on the market with a request for fast-enactment of fitting new crimes, or alteration of the existing ones through amendments, could hardly work in this domain. The panacea for this problem seems to have been found primarily in the concept of 'all-embracing' blanket securities crimes in the US. As it will be seen in more detail below, this means that securities laws operate with such wide-reaching formulation that makes a crime out of any willful violation of any provision of these laws by any person.

Third, although the securities statutes as 'blanket all-embracing criminal laws' have been readily available from the 1930s on, a trend of intensified criminalization of federal regulatory statutes, as well as considerably more frequent resort to the blanket crimes, has begun in the early 1970s only. As a 1998 Study of the American Bar Association (ABA) revealed, "more than $40 \%$ of the federal criminal provisions enacted since the Civil War have been enacted since 1970." 36 This process was not limited to the securities domain though. In the context of securities laws, this meant the arrival of the 'insider trading' era as a result of what, as if guided by an invisible hand, criminal law reappeared on the scene with heightened force. One could say that this breakthrough was the product of the realization, spanning over more areas of law, that the paraphernalia of criminal law, indeed, could be adapted to more efficiently combat fraud and other criminal behavior than earlier; though as the empirical evidences suggest criminal law is hardly omnipotent either.

As opposed to the US, in Europe, the importance of criminal law has undoubtedly increased as well in the domain yet with substantial delays: first in the first part of the 1990s with the criminalization of insider dealing, and then with the passage of related $21^{\text {st }}$ century pieces of legislation,

36 ABA Task Force on Federalization of Criminal Law, 1998, Task Force Report, p. 10. Cited by O'Sullivan, J., 2006, The Federal Criminal 'Code' Is a Disgrace: Obstruction Statutes as Case Study, Journal of Criminal Law \& Criminology, Vol. 96, No. 2, note 23, p. 647. 
as already hinted at above. This could be read out also from the available empirical evidences. In the UK, for example, the first successful criminal conviction for insider dealing dates to year 2009 only. ${ }^{37}$ Still, contrary to competition (antitrust) law where administrative remedies dominate continuedly, in the securities domain the balance seems to have tilted more towards criminal enforcement.

Last, as part of this post-1970s reinvention of criminal law in the US, numerous new crimes were enacted to "augment the existing general prohibitions on fraud," often because of "political desire to react to a given scandal." 38 This was the case with $21^{\text {st }}$ century corporate scandals of the ENRON caliber or the 2007 Credit Crunch. The outcomes of these were the 2002 Sarbanes and Oxley- and the 2010 Dodd-Frank Wall Street Reform and Consumer Protection Acts respectively; ${ }^{39}$ both with rewritten criminal provisions. The former, for example, introduced a purportedly new crime named exactly as its Great Depression predecessor: 40 'securities fraud. ${ }^{41}$ During the last few years, apart from increased focus on the online world, the other noticeable trend in the US was the stiffening of penalties imposed for securities crimes. ${ }^{42}$ These weak points of the US system should not be neglected either by the reader especially as teething problems resembling the American phenomenon of 'hyper-criminalization' seems to have surfaced, for example, already in Serbia as well. ${ }^{43}$

\subsection{THE TECHNIQUES BEHIND THE EXPANSION}

Without pretension of completeness, seven techniques employed by the US federal criminal system to combat securities crimes are here offered as explanations for the comparatively higher success rate of US criminal prosecutions in the domain. These, resorting to some linguistic

37 R v. McQuoid, Southwark Crown Court, 27 March 2009 (unreported), cited by Gullifer, L., Payne, J., 2011, Corporate Finance Law - Principles and Policy, Oxford University Press, note 39, p. 462.

38 O’Sullivan, J., 2006, p. 654.

39124 Stat. $1376-2223$.

40 See, e.g., Falvey, J. J. Jr., Wolfman, M. A., 2002, The Criminal Provisions of SarbanesOxley: A Tale of Sound and Fury, White-Collar Crime Reporter, Vol. 16, No. 11, p. 1.

41 Public Company Accounting Reform and Investor Protection Act (hereinafter: Sarbanes \& Oxley Act) $\$ 1348$.

42 See Joynston, N., 2020, Securities Fraud, American Criminal Law Review, Vol. 57, No. 3, p. 1330 et seq. Joynston's example is the 2017 case of United States v. Kluger, 722 F.3d 549 (3d Cir. 2013), in which a twelve-year prison term was meted out for participation in a seventeen-years-lasting insider trading scheme; the longest recorded sentence up until 2013.

43 Kostić, J., Trošić, S. J., 2020, p. 615. 
innovation with respect to the first two categories, are: 1 / blanket criminal securities statutes and blanket securities crimes, 2/ all-embracing securities crimes, 3 / the deference attributed to SEC's interpretations (Chevronand Skidmore deference), 4/ the procedural possibility of the combined use of sectoral and general crimes, 5/ sufficiency of circumstantial evidence, as well as 6/ the various forms of cooperation of the SEC and prosecutorial offices. These will be discussed in the following primarily based on federal laws.

The seventh element undoubtedly deserving mention, however, is a State law peculiarity: the revolutionary (and by the industry heavily criticized) solutions of New York's Martin Act. In particular, the rule according to which intent is not to be proven in case of securities fraud (save some exceptions).

\subsubsection{Blanket Crimes: European Terminology for American Law?}

The sector-specific crimes enshrined into the federal securities acts, indeed, would qualify as 'blanket-crimes' in 'blanket criminal laws' as perceived in (some) Continental European jurisdictions. Some other US federal statutes would qualify as such, like the famous tandem of antitrust laws, the Sherman- ${ }^{44}$ and the Clayton Acts. ${ }^{45}$

Unfortunately, the pair of terms that Continental Europeans use for the above-mentioned "out-posted" sectoral criminal provisions in the securities statutes, has no English commonly accepted equivalent. As noted by some European scholars, "[t]he term Blankettstrafgesetz cannot be translated literally [for what reason, for example] Bohlander [...] uses the translation 'blanket Acts' [...]." 46 The metaphrased (mirror-image) translation of the German term "Blankettstrafgesetz" would thus be "blanket penal (or criminal) act.' As already hinted at, these are resorted to when the criminal codes (or statutes) "they themselves do not contain (all) the elements of the offence, but refer to other legislation for that purpose." ${ }^{7}$ Quite a number of other Continental European local languages do possess special expressions similar to the German one, like the Croatian and

44 The Sherman Antitrust Act of 1890 (26 Stat. 209, codified at 15 U.S.C. $\$ \$ 1-7$ ). See $\$$ 2 of the Sherman Act titled 'Monopolizing trade a felony; penalty'.

45 The Clayton Antitrust Act of 1914 (Pub.L. 63-212, 38 Stat. 730, enacted October 15, 1914 , codified at 15 U.S.C. $\$ \$ 12-27,29$ U.S.C. $\$ \$ 52-53)$. See $\$ 21(1)$ on 'Penalties.'

46 Ladiges, M., 2013, Criminal Liability of Directors of a Private Limited Company Seated in Germany, Criminal Law Forum, Vol. 24, No. 1, note 58, p. 101.

47 Bohlander, M., 2009, Principles of German Criminal Law, Hart Publishing, Oxford, p. 23. 
Serbian 'blanket norms' (blanketne norme). ${ }^{48}$ The Hungarian expression is rather a variation emphasizing that in case of these crimes only the 'frame' of a crime is set (keretdiszpozíció). ${ }^{49}$

While the US federal securities statutes do fit under the German definition of blanket acts, there is another major discrepancy, too. Namely, the German Basic Law (Grundgesetz), the constitution, requires as well "that criminal liability must be based on a full act of Parliament." 50 This, in other words, means that the blanket act must be a piece of legislation, a criminal code or a criminal statute. In this respect US securities criminal laws contradict the definition of blanket acts as per German law, given that willful violation of the provisions of sub-statutory level sources of law - rules and regulations - would also qualify as a crime in the US. ${ }^{51}$ The German law-originated designations, 'blanket acts' and 'blanket crimes' nonetheless can be used herein to ease communication.

This discussion on blanket criminal acts is of importance for us because they represent one important method whereby the confines of criminal law have expanded. In the western hemisphere, the process of increased resort to blanket laws dates back to the 1970s and the emergence and growth of the 'regulatory state', 52 though, in the domain of US securities regulations, these species of tectonic changes had occurred already in the 1930s. Some Continental European systems attribute less importance to blanket crimes as tools exploitable to protect investors and the integrity

48 The leading former Yugoslav, two-volume Legal Encyclopedia ("Pravna enciklopedija”), published in 1989, did define such 'blanket' or 'norms fixed by statutes different from the criminal code' and cautioned against their use. The definition provided that the "The blanket norm [is such a] legal norm in which the sanction (punishment) is not fixed but is left to be determined by another [act]." Pravna enciklopedija, volume one, Belgrade, Savremena administracija, p. 121.

49 On the topic see, e.g., Wiener, I. A., 2001, A Büntető Törvénykönyv Szerkezete - A szakmai büncselekmények és az értelmező rendelkezések (The Structure of the Criminal Code - Professional Crimes and the Interpretative Provisions), Büntetöjogi Kodifikáció, Vol. 2001, No. 1, p. 12.

50 Bohlander, M., 2009, p. 23. The referred to article 103(2) of the Basic Law reads: "An act may be punished only if it was defined by a law as a criminal offence before the act was committed."

5115 U.S. Code $₫ 78 \mathrm{ff}$ - Penalties reads: “(a) Willful violations; false and misleading statements - Any person who willfully violates any provision of this chapter (other than section $78 \mathrm{dd}-1$ of this title), or any rule or regulation thereunder the violation of which is made unlawful or the observance of which is required under the terms of this chapter [...]."

52 See, e.g., Section 122(1) of the Ontario Securities Act, R.S.O. 1990, c.S.5, which also operates with 'all-embracing crimes.' For blanket crimes in the United Kingdom, see Part XXVII 'Offenses' in the Financial Services and Markets Act 2000 (2000 c. 8), as amended by Section 92, Part 7, of the Financial Services Act 2012 (2012 c. 21). 
of securities markets, what could easily be seen from the lack of penalty provisions in sectoral statutes. ${ }^{53}$

\subsection{2. 'All-Embracing' Sector-Specific Crimes}

Besides the 'blanket' nature of the US federal securities statutes, another linked technique further expands the possible reach of the criminal prong. In the lack of a commonly accepted designation, ${ }^{54}$ this regulatory technique will be referred to herein with the short-hand expression of 'all-embracing crimes'. These are actually such 'blanket crimes' that expand over the entire area within the purview of a specific securities statute (e.g., the 1934 Securities Exchange Act). This is achieved, put colloquially, through the three sweeping 'any-words' in the statutory text criminalizing 'any' willful violation of 'any' substantive provision of the statute (or sub-statutory rules and regulations) by 'any person. ${ }^{55}$

53 For example, the Austrian Capital Market Act "Kapitalmarktgesetz" (BGBI. I Nr. 62/2019) and the Hungarian Act of year 2001 No. CXX on Capital Market (2001. évi CXX. törvény a tökepiacról) operate exclusively with administrative punishments. As opposed to that, the 1994 German Securities Trading Act ("Gesetz über den Wertpapierhandel”) (BGBI. I S. 2708, last amended on 12 September 2020) contains a detailed blanket criminal provision $(\$ 119)$.

54 Notwithstanding the unquestionable importance of 'all-embracing crimes,' no specific legal term seems to exist to cover this type of crimes in the US. US sources rather resort to description, just like international scholarly publications. Only a handful of papers could be found on the internet using the expressions all-embracing or all-encompassing crimes. While the few US sources use the former, elsewhere rather the other variant dominates. Yet it is not only the context of securities laws where these phrases surface. Drumbl, for example, spoke of 'all-embracing criminal justice' in his paper devoted to war crimes, specifically in Bosnia and Herzegovina, though with a meaning different from the one focused upon herein. Drumbl, M. A., 2017, The Two Illusions of All-Embracing Criminal Justice and Exclusively Extrajudicial Responses to Mass Atrocity, in: Bergsmo, M. (ed.), Abbreviated Civil Procedures for Core International Crimes, Torkel Opsahl Academic Publisher, Brussels, p. 20.

5515 U.S. Code $\$ 78 \mathrm{ff}$ - Penalties. As this is less known outside the US, it makes sense to reproduce the text of subsection $\$ 78 \mathrm{ff}(\mathrm{a})$ : “Any person who willfully violates any provision of this chapter (other than section $78 \mathrm{dd}-1$ of this title), or any rule or regulation thereunder the violation of which is made unlawful or the observance of which is required under the terms of this chapter, or any person who willfully and knowingly makes, or causes to be made, any statement in any application, report, or document required to be filed under this chapter or any rule or regulation thereunder or any undertaking contained in a registration statement as provided in subsection (d) of section 780 of this title, or by any self-regulatory organization in connection with an application for membership or participation therein or to become associated with a member thereof which statement was false or misleading with respect to any material fact, shall upon conviction be fined not more than $\$ 5,000,000$, or imprisoned not more than 20 years, or both, except that when such person is a person other than a natural person, a fine not exceeding $\$ 25,000,000$ may be imposed; but no person 
All-embracing crimes actually are known also to the German doctrine on blanket crimes yet under different designations and depending on how the contents of blanket crimes are to be filled. Two types of such delegated lawmaking are differentiated. In case of type one, the blanket criminal act defines the contents of blanket crimes as precisely and as narrowly as possible. These are known as 'norm-concretizing' (normkonkretisierende) blanket criminal statutes. As opposed to that, in case of the so-called 'norm-expanding' (normergänzende) ones, ${ }^{56}$ substantial flexibility is given to the body entrusted with content-determining. The US all-embracing crimes enshrined into the federal securities statutes seem to represent examples of the latter category due to the mentioned 'triple-any' statutory language.

The securities acts passed as a reaction to the Great Depression "do not contain specific designations indicating when the commission of a proscribed act or the failure to perform a required act will constitute a criminal offense." ${ }^{57}$ Rather, content-wise, the penalty provisions of the securities acts are spoken of as being made of three types of norms. Two are of less importance to us because one of them merely prescribes the maximum penalties (fines and imprisonment) that might be imposed upon conviction. The other attributes making of certain willful false filings a distinct category of crime by express language. ${ }^{58}$

The most important of the three, however, is what is in the centerfold of our investigations, the all-embracing crimes, which represent a "general proscription making willful violation [by any person] of any substantive provision of the statute or any rule or regulation promulgated thereunder a crime." 59 The broad reach of this provision through the 'any' language and its extension also to sub-statutory rules and regulations is one important technique that allows expansive interpretation. The broad reach, indeed, increases the powers of prosecutors in charging and plea

shall be subject to imprisonment under this section for the violation of any rule or regulation if he proves that he had no knowledge of such rule or regulation." [Emphasis added.]

56 Ernst, G. P., 2017, Blankettstrafgesetze und Ihre Verfassungsrechtlichen Grenzen [Blanket Laws and their Constitutional Limitations], Springer, Wiesbaden, p. 36.

57 Mathews, A. F., 1971, p. 904.

58 Note that while in case of all-embracing crimes, both under Section 24 of the 1933 Act, and Section 32(a) of the 1934 Securities Exchange Act, the prerequisite mens rea is 'willful' violation. As opposed to that, false filing under "the second clause of $\$ 32$ (a) [of the $1934 \mathrm{Act}$ ] relating to false or misleading statements in various papers required to be filed" requires acting 'willfully and knowingly.' Quoted from the leading case of United States v. Dixon 536 F.2d 1388 ( $2^{\text {nd }}$ Cir., 1976).

Mathews, A. F., 1971, p. 905. 
bargaining. ${ }^{60}$ The all-embracing nature of securities crimes inevitably helps not only the work of prosecutors, ${ }^{61}$ but also the SEC, and courts deciding securities cases by charting the scope of federal crimes.

\subsubsection{Proving Scienter under New York's Martin Act}

As we are interested in how law is helping the work of the SEC, prosecutors and courts in combating securities crimes, mention must be made also of New York's Martin Act. ${ }^{62}$ Namely, federal securities regulations criminalize 'willful' (or willful and knowing) ${ }^{63}$ conduct only. Willfulness is, however, very hard to prove in this peculiar domain notwithstanding that circumstantial evidence is also acceptable.

New York's Martin Act with its anti-fraud provisions ${ }^{64}$ clearly stands out in this respect, as contrary to federal securities laws, it does not require proving of intent to defraud (save some exceptions). Assessing the defendants objection that 'they lacked specific intent to defraud', in the case People v. Sala, ${ }^{65} \mathrm{New}$ York State's Supreme Court proclaimed that "[...] neither scienter, nor an intent to defraud need to be proven in order to establish liability under the Martin Act." ${ }^{66}$ No wonder that the Act was labeled by the industry as the severest anti-fraud State statute "[arming] the New York Attorney General with extraordinarily broad powers to investigate and combat securities fraud." 67

60 O’Sullivan, J., 2006, p. 653.

61 Ibid.

62 As a law of the State of New York, the Martin Act applies in case of "sale or promotion of a security within or from New York," when "misrepresentation, omission of a material fact, or conduct which deceives or misleads the public." Gordon, H. K., 2015, Enforcement Proceedings under New York's Martin Act, Practical L.J. - New York Litigation, Vol. 20, No. 26, p. 22.

63 The 'willfully and knowingly' applies only to false filings under the 1934 Exchange Act.

64 New York General Business Law, art. 23-A, ss. 352-353.

65695 N.H.S. 2d 169 (App. Div. 1999). In the case, codefendants were charged with 39-count indictment for fraud committed related to sale of financial plans consisting of numismatic coins and art portfolios, as well as condominiums located in Florida and Indiana. The investigations revealed, in particular, that investors were not informed about certain fees associated with the marketing of these financial plans, large commissions charged, nonliquidity of the investments, and risks associated with these markets. It was also proven that the Chief Operating Officer (Sala) directly participated in many of the related activities (formulating the art portfolio profit projection sheets, receipt commission from every art sales and attendance at board meetings as executive art consultant), which were those circumstances from which the court could have inferred that he knew about the fraud and thus possessed the required intent (mens rea) - even though the Martin Act does not require proving it.

66 Ibid., section B, p. 4.

67 Gordon, H. K., 2015. 
Otherwise, the act's history is not only curious but telling as well. It was passed back in 1921, in the era of 'blue sky' laws, ${ }^{68}$ when it had not really caused much upheaval. It had been left unscathed by the passage of the New Deal securities statutes in the 1930s and 1940s as well, to remain dormant thereafter until the appointment of Eliot Spitzer as Attorney General in 1998. He (just as his successors) managed to exploit the Martin Act successfully against big names on the Wall Street. ${ }^{69}$ This was possible not only because the Attorney General was vested with enormous investigative and enforcement powers (as no State-level SEC was established by the act), but - as already hinted at - because of the rule as per which the State is not required to prove scienter (i.e., intent to defraud) save in some exceptional situations. ${ }^{70}$

\subsubsection{Chevron- and Skidmore-Deference to SEC Construction of Federal Securities Statutes}

As an agency staffed by experts, the SEC has played a crucial role in detecting securities crimes and otherwise assisting their criminal prosecution since its establishment in 1934; from supplying evidence, interpreting the provisions of sectoral statutes, through promulgating sectoral rules and regulations. Consequently, courts have often heeded SEC's opinion. Yet as the courts act also as checks on what the SEC as an administrative body belonging to another branch of the government is doing, the number of cases in which SEC did not prevail, ${ }^{71}$ or SEC's rule was struck

68 The expression 'blue sky laws' refers to "[t]he [state] statutes, which vary widely in their terms and scope. [Several explanations are given to this appellation.] It has been said, for example, that the Kansas legislature was spurred by the fear of fast-talking eastern industrialists selling everything including the blue sky." Hazen, T. L., 1995, Treatise on the Law of Securities Regulation, Thomson-West, $3^{\text {rd }}$ ed., pp. 490-92; cited by the Black's Law Dictionary.

69 See Gordon, H. K., 2015 and McTamaney, R. A., 2003, New York's Martin Act: Expanding Enforcement in an Era of Federal Securities Regulation, Washington Legal Foundation, (https://www.clm.com/docs/2-28-03mctamaney.lb.pdf, 6. 3. 2021).

70 New York General Business Law \$352-c (5), (6). See also Gordon, H. K., 2015, p. 22. The attorney general may prosecute criminal violations of the Martin Act (misdemeanors and Class E felonies). Ibid. In New York, as in other states, felony is "[a] serious crime usually punishable by imprisonment for more than one year" Black's Law Dictionary. The imposable sentence is maximum four and minimum one year for Class $\mathrm{E}$ felonies fixed by the court based on a number of factors. Consolidated Laws of New York, Penal, Part 2, Title E (Sentences), Article 70(2)(e) - Sentence of imprisonment for felony, (https://www.nysenate.gov/legislation/laws/PEN/70.00, 6. 3. 2021).

71 See, e.g., SEC v. Sloan 98 S.Ct. 1702 (1978). In the case, the SEC issued a series of orders suspending the trading in shares of stocks, out of which the petitioner owned 13, based on $\$ 12(\mathrm{k})$ of the Securities Exchange Act 1934. This provision gives the power 
down by courts, is far from being negligible, either. SEC's records could be exemplary wouldn't it be for such major failures of SEC as the detection of the notorious Madoff Ponzi scheme, ${ }^{72}$ and many other less-known scams. These should make realize regulators what the limits of even the best equipped, financed and staffed governmental agencies are, and what realistically could be expected from them.

As we are interested how the body of securities crimes is given content to and what factors shape their contours, the role SEC's construction of statutory provisions play in that respect need to be taken a look at next.

The distinction of US law, not limited to the securities context, is that the role SEC's construction of statutory texts plays in courts was given a formal recognition to in the US Supreme Court's milestone decision of Chevron U.S.A., Inc. v. Natural Resources Defense. ${ }^{73}$ This case gave birth to the "two-part test under which a court will uphold a federal agency's construction of a federal statute;" 74 named after the case as 'Chevron deference.' The gist of the test is that a court is to "uphold a federal agency's construction of a federal statute if $1 /$ the statute is ambiguous or does not address the question at issue, and $2 /$ the agency's interpretation of the statute is reasonable." 75 The logic of the test would ring the bell in the ears of European lawyers as well given that it rests on the realization that judges are not necessarily experts in those fields in which the Congress "has delegated policy-making responsibility to an agency [and as result of what judges can rely on the construction of federal statutes for resolution of competing interests] which Congress itself either inadvertently did not resolve, or intentionally left to be resolved by the agency charged with the administration of the statute in light of everyday realities."76 Chevron deference therefore applies only if "appropriate congressional delegation of power"77 exists.

to SEC to "suspend ... summarily trading in any security ... for a period not exceeding ten days." The SEC lost because the repeatedly imposed ten days lasting suspension orders had lasted in effect for over a year. According to the opinion of the Supreme Court, the SEC was not empowered to issue a series of such orders "based on a single set of circumstances."

72 See, e.g., Nichols, C., 2011, Addressing Inept SEC Enforcement Efforts: Lessons from Madoff, the Hedge Fund Industry, and Title IV of the Dodd-Frank act for U.S. and Global Financial Systems, Northwest Journal of International \& Business Law, Vol. 31, No. 3, p. 637.

73104 S. Ct. 2778 (1984). The case concerned the construction of the term 'stationary source' under the Clean Air Act by the Environmental Protection Agency; the SEC was not involved.

74 Black's Law Dictionary.

75 Ibid.

76 Chevron U.S.A., Inc. v. Natural Resources Defense Council, Inc., 467 U.S. 837, 843-44 (1984), judgment, p. 2793.

77 Ibid. (deference rests on either express or implied delegation of power to agency). 
Yet deference to agency (including SEC) construction of federal securities statutes had been given by courts even before the Chevron case without express or implied delegation of power to an agency. After the 1944 Skidmore v. SWIFT \& $\mathrm{Co}^{78}$ case this was distinctively labeled as the 'Skidmore-deference.' Skidmore rests on the presumption that "the court cannot ignore the agency interpretation - the court must assess that interpretation against multiple factors and determine what weight they should be given. [After what,] however, agency interpretations receive various degrees of deference, ranging from none, to slight, to great, depending on the court's assessment of the strength of the agency interpretation under consideration."79

The position of Justices of the US Supreme Court was split on the question whether there is a continued need for Skidmore-deference after Chevron: Justice Scalia was the only to claim that Skidmore was an anachronism. ${ }^{80}$ Diver characterized Skidmore as "nothing more than 'respect of courteous regard' [...]." 81 Yet Skidmore seems to have survived Chevron as "serving a supplementary or backstopping role to Chevron," 82 a test based on 'the power to persuade. 83

Deference is often expressed in court judgments explicitly; and not only when interpretation of criminal laws is at stake. In a 1991 watershed case, ${ }^{84}$ in which the court had to decide whether a new computer-based trading system, with three participants, is an exchange or rather a clearing house, the court yielded to the opinion of the SEC. It eloquently admitted that " $[\mathrm{t}]$ he Securities and Exchange Commission can determine better than we generalist judges whether the protection of investor and other interests within the range of the statute is advanced, or retarded [in particular as] [a]n administrative agency has discretion to interpret a statute that is not crystal clear."

7865 S.Ct. 161 (1944).

79 Merrill, T. W., Hickman, K.E., 2001, Chevron's Domain, Georgetown Law Journal, Vol. 89, No. 4, p. 855. (Deference to agency interpretations operates along a sliding scale).

80 His skepticism is expressed in his concurring opinion in EEOC v. Arabian Am. Oil Co., 499 U.S. 244, 259 (1991), p. 1236.

81 Diver, C. S., 1985, Statutory Interpretation in the Administrative State, University of Pennsylvania Law Review, Vol. 133, No. 3, p. 564.

82 Merrill, T. W., Hickman, K. E., 2001, p. 855.

83 For example, in the Christensen v. Harris County [120 S.Ct. 1655, 2000] the Supreme Court declared that informal agency statements are not entitled to Chevron deference but only "respect" under the Skidmore doctrine.

84 Board of Trade of the City of Chicago v. Securities and Exchange Commission 923 F.2d 1270 ( $7^{\text {th }}$ Cir., 1991). SEC was of the opinion that the new 'Delta System' was not an exchange but a clearing house. The Chicago Board of Trade disagreed because it was concerned about competition for the market from the side of SEC. 


\subsubsection{The Utility of the Combination of Sector-Specific and General Crimes in Prosecuting Securities Crimes}

What data from the US suggest is that the very existence of all-embracing blanket crimes has hardly made general crimes redundant in prosecuting securities fraud. In fact, prosecutors do make continuedly extensive use also of general crimes to combat securities fraud, in particular federal mail- and wire fraud statutes because of their "simplicity, adaptability, and comfortable familiarity;" as formulated by Judge Rakoff in his often quoted passage. ${ }^{85}$ Bernard L. Madoff, the schemer behind the largest Ponzi scheme in the US, prosecuted and sentenced to 150 years, as well as fined with $\$ 170 \mathrm{bn}$, was charged with "eleven felony charges including securities fraud, investment adviser fraud, mail fraud, wire fraud, three counts of money laundering, false statements, perjury, false filings with the United States Securities and Exchange Commission ("SEC"), and theft from an employee benefit plan." 86

What matters is that it would clearly be mistaken to claim that securities criminal law has been dead letter on paper in the US, though ups and downs in the frequency of the prosecution of various securities crimes are noticeable. ${ }^{87}$ The SEC may partly be also blamed for the fluctuation as its priorities in making criminal referrals have logically varied over time. ${ }^{88} \mathrm{At}$ any event, closer attention to the possibility of the combined use of general and blanked crimes in this domain, its pros and cons, might deserve more attention; in Europe well.

85 The full passage reads: "To federal prosecutors of white collar crime, the mail fraud statute is our Stradivarius, our Colt 45, our Louisville Slugger, our Cuisinart - and our true love. We may flirt with RICO [Racketeer Influenced and Corrupt Practices Act of 1970], show off with 10b-5, and call the conspiracy law darling, but we always come home to the virtues of 18 U.S.C. $\$ 1341$, with its simplicity, adaptability, and comfortable familiarity." Rakoff, J. S., 1980, The Federal Mail Fraud Statute (Part I), Duquesne Law Review, Vol. 18, No. 4, p. 771.

86 See the related press release as of 2009, (https://archives.fbi.gov/archives/newyork/ press-releases/2009/nyfo031009.htm, 6. 3. 2021).

87 The long list of Mathews from the beginning of the 1970s involved - just to list the most interesting ones - manipulation of the listed and unlisted securities, short selling violations, filing false reports, churning, false insider "ownership" reports, as well as illegal pledging (hypothecation) of clients' securities. Ibid, p. 909.

88 At the beginning of the 1970s, for example, SEC investigations (often leading to criminal referrals) were concentrated on three types of cases: first, cases involving "chronic violators, who through the years have repeatedly appeared as defendants, co-conspirators, respondents, or 'fringe' participants in fraudulent securities promotions," second, egregious or violations that were in those days 'fashionable schemes', and third, corruption, or attempted corruption of SEC staff cases. See Mathews, A. F., 1971, p. 916. 


\subsubsection{Sufficiency of Circumstantial Evidence}

The little-explored evidentiary question of relevance to our subject matter concerns the possibility of using circumstantial evidence in prosecuting securities crimes. As a reminder, circumstantial, or indirect evidence "[is] based on inference and not on personal knowledge or observation." ${ }^{89}$ It represents "[e]vidence of some collateral fact, from which the existence or non-existence of some fact in question may be inferred as a probable consequence." ${ }^{90}$

The basic contours of the law on circumstantial evidence are essentially the same on both federal and State levels in the US. First and foremost, in principle, direct and circumstantial evidence are of equal value. ${ }^{91}$ As expressed by a US court: "Direct evidence is not required to support a conviction; in fact, the government is entitled to prove its case solely through circumstantial evidence, provided that the government still demonstrates each element of the charged offense beyond a reasonable doubt." 92

It is to be noted also that in the US generally much more attention and detail is devoted to the role of evidence and evidentiary standards than in many Continental European systems, in the context of both, private securities fraud actions ${ }^{93}$ and in criminal proceedings. As we are here concerned with the latter only, the underlying justification, often cited in cases, reads as follows: "Because intent is an invisible operation of the mind, direct evidence is rarely available in the absence of an admission, and is unnecessary where there is legally sufficient circumstantial evidence of intent." ${ }^{2}$ All the nuances of what this means obviously cannot be stated here. Let us here provide the reader nonetheless with a more concrete example what this means. In the 2010 U.S. v. Lewis ${ }^{95}$ federal case, involving defendants convicted, among

89 Black's Law Dictionary, 2009.

90 Richardson, W. P., 1928, The Law of Evidence, $3^{\text {rd }}$ ed., Brooklyn Law School, p. 68.

91 See, e.g., Holland v. U.S., 348 U.S. 121, 40 (1954) stating that circumstantial evidence "may in some cases point to a wholly incorrect result, [but that this is] 'equally true' of direct evidence". Cited by Buell, S.W., Kern, G.L., 2012, On the Mental State of Consciousness of Wrongdoing, Law and Contemporary Problems, Vol. 75, No. 2, note 82, p. 155.

92 U.S. v. Lorenzo 534 F.3d 153 ( $2^{\text {nd }}$ Cir. 2008), para 2, p. 153. (Case in which the defendants were convicted for conspiracy to import cocaine.)

93 See, in particular, Tellabs, Inc. v. Makor Issues \& Rights, Ltd. 551 U.S. 308, 127 S.Ct. 2499, 168 L.Ed.2d 179. See also Coffee \& Sale 2009, note 14 supra, p. 1051 et seq.

94 People v. Rodriguez 957 N.E. 2d 1133 (N.Y. 2011), para 2, at 1133. (The court proclaimed that "Evidence regarding defendant's possession of forged identification documents at time of his arrest was sufficient to establish his intent to defraud, deceive, or injure, as required to support conviction [...]").

95594 F.3d 1270 ( $10^{\text {th }}$ Cir. 2010). The scheme orchestrated by the defendants through a number of ostensible 'investment companies,' promised returns from investments 
others, also for securities fraud (organization of a Ponzi scheme), it was mentioned that proving fraud does not require testimony of the victims. ${ }^{96}$

\subsubsection{Cooperation of the SEC and Prosecutorial Offices}

The basic rules is that "[t]he SEC ... has no power to bring criminal actions for willful violation of the federal securities laws [and] [t]he Commission's authority is limited to referring potential criminal actions to the Justice Department." 97 Yet the 'cooperation' between the two does not stop here. In particular, as parallel civil and criminal proceedings are possible in the securities domain, backed up by express statutory language, SEC is authorized to share information gathered by it with the Attorney General. ${ }^{98}$ As a result, SEC's investigations often become indispensable instrumentalities in the hands of prosecutors as well, what denotes not only sharing of data and information but also possibility to exploit the "expertise" of SEC otherwise as well. ${ }^{99}$ These together represent yet another element of the puzzle of 'what makes the system work.'

The issue is not only that more comparative studies would be needed to more clearly see all the dimensions of the interplay but that this is such a factor that is harder to replicate elsewhere. For sure, a properly structured interplay as a complex relationship can hardly be introduced by formal enactment of a few new crimes.

\section{The Missing Piece of the Puzzle: the Abolition of Common Law Crimes}

That the Nullum crimen sine lege, nulla poena sine lege maxim is foundational for Continental European legal regimes is expressed by the

into high yield bonds the principal of which was claimed to be guaranteed by reputable insurers. As is the case with Ponzi schemes, the moneys collected were not invested in any bonds but were consumed by the schemers and paid to first-generation investors. The scheme operated relatively long, from 1999 until late 2004, and generated more than $\$ 40$ million losses.

96 Ibid., p. 1275.

97 See, e.g., the last sentence of Section 21(d) of the 1934 Securities Exchange Act, which reads: "The Commission may transmit such evidence as may be available concerning such acts or practices as may constitute a violation of any provision of this chapter or the rules or regulations thereunder to the Attorney General, who may, in his discretion, institute the necessary criminal proceedings under this chapter." See also Coffee, J. C. Jr., Sale, H. A. 2009, note 14 supra, p. 1363.

98 See, in particular, SEC v. Dresser Industries 628 F.2d, p. 1376.

99 For a discussion on parallel civil and criminal proceedings in the securities domain see Sinha, P., 1989, Parallel Civil and Criminal Proceedings, American Criminal Law Review, Vol. 26, No. 3, pp. 1217-1238. 
eminent position it is attributed to it by criminal codes (or statutes). In fact, in many it is the very first article that proclaims it. ${ }^{100}$ Given the above-discussed expansion of securities crimes and having in sight that not long ago courts, indeed, were empowered to make new crimes in Ameri$\mathrm{ca}$, two further legitimate questions ought to be answered. The first is what has happened to common law crimes? Have they completely disappeared from federal and the laws of the States? The other one being whether the above-canvassed methods whereby the realm of securities criminal laws are expanding could be reconciled with the just mentioned, most venerable, maxim of criminal law?

When answering the above questions, it should be borne in mind that, first, the principle of "no crime without law, nor punishment without law" is also part of both federal and State criminal laws in the US today. Although according to the federal Constitution, the power to create crimes belongs primarily to the States, the federation is also empowered to prohibit and punish "offenses specially related to federal interests (including crimes committed on property of exclusive federal jurisdiction such as military bases, crimes against certain federal officers, and crimes that involve conduct in more than one state [...] such as organized crime offenses." 101 The maxim is materialized in the 'legality principle,' which "[i]n its modern form [means] that criminal liability and punishment can be based only upon a prior legislative enactment of a prohibition that is expressed with adequate precision and clarity." 102

The outset of the process "towards comprehensive revision of statutory provisions governing substantial criminal law matters," 103 including gradual abolition of common law crimes, is to a great extent linked to the

100 See, e.g., $\$ 1$ of the Austrian Criminal Code ("Bundesgesetz vom 23. Jänner 1974 über die mit gerichtlicher Strafe bedrohten Handlungen" (Strafgesetzbuch - StGB) StF: $B G B l$. Nr. 60/1974 as amended), Article 2 of the Croatian Criminal Act ("Kazneni zakon", Narodne novine, No. $125-11$ as amended), $₫$ of the German Criminal Code ("Strafgesetzbuch in der Fassung der Bekanntmachung vom 13. November 1998 (BGBl. I S. 3322)"), Article 1 of the Italian Criminal Code ("Codice Penale"), Section 1 of the Polish Criminal Code 1997 (Ustawa z dnia 6 czerwca 1997 r. - Kodeks karny as amended), Article 1 of the Serbian Criminal Code (Krivični zakonik, Official Gazette of RS, No. 85/2005 as amended) and Article 1 of the Spanish Criminal Code ("Organic Law 10/1995, of 23 November, of the Criminal Code, "Ley Orgánica 10/1995, de 23 de noviembre, del Código Penal").

101 Robinson, P. H., Dubber, M. D., 2007, The American Model Penal Code: A Brief Overview, New Criminal Law Review, Vol. 10, No. 3, p. 319.

102 Robinson, P. H., 2005, Fair Notice and Fair Adjudication: Two Kinds of Legality, University of Pennsylvania Law Review, Vol. 154, No. 2, p. 336.

103 Dix, G. E., Sharlot, M. M., 2008, Criminal Law - Cases and Materials, $6^{\text {th }}$ ed., St. Paul, Thomson-West, p. 7. 
approval of the final draft of the Model Penal Code by the American Law Institute (ALI) in 1962. Prior to the revision movement, State and federal statutes suffered from more defects; in particular, substantive criminal law was not addressed comprehensively, penalties lacked consistency and "[n] o effort was made in the statutes to define the various offenses but instead common law and sometimes [latest-generation] judicial formulations of the elements of the crimes were incorporated or developed ".104

The States have employed various methods in the long process leading to the abolishment common law crimes. This evolutionary phase could be said to have been completed had it not been for two groups of States: one abolishing only the common law offenses but not common law defenses, and the other one keeping common law crimes unless not contrary with their criminal codes. Besides these two, Robinson ${ }^{105}$ identified two more groups of States, both having more radically implemented this task yet following different routes. While the first simply declared that common law crimes are abolished (a formula embraced by ALI's 1962 Model Penal Code as well), ${ }^{106}$ the second rather "provide[d] that no act or omission is a crime unless made so by the code or applicable statute."

The answer to the question whether there are common law crimes is easier to answer as far as the federal level is concerned as the US Supreme Court has unequivocally declared that it is the legislature that makes crimes exclusively. As proclaimed in the 1980 case of Whalen v. United States, "the power to define criminal offenses and to prescribe the punishments to be imposed upon those found guilty of them resides wholly with the Congress." Courts, ${ }^{107}$ let alone administrative agencies, ${ }^{108}$ have no powers to create new crimes. Consequently, the above-discussed all-embracing crimes are not to be perceived as crimes made by the SEC or the courts.

$104 \mathrm{Ibid}, \mathrm{p} .7$. For a detailed discussion on the defects and weak points of the pre-Model Penal Code laws see, in particular, Wechsler, H., 1952, The Challenge of a Model Penal Code, 65 Harvard Law Review, Vol. 65, No. 7, p. 1100-01; and Frank, J., Remington, F. J., 1954, Criminal Law Revision Codification vs. Piecemeal Amendment, Nebraska Law Review, Vol. 33, No. 3, pp. 396-407. Professor Wechsler of Columbia University Law School was the Chief Reporter for the Model Penal Code.

105 Robinson, P. H., 2005, pp. 339-340.

106 The Model Penal Code was adopted at the 1962 Annual Meeting of the American Law Institute at Washington, D.C. (24 May 1962), (https://www.ali.org/publications/ show/model-penal-code/, 6. 3. 2021). Its Section 1.05(1) titled 'All Offenses Defined by Statute' foresees that: "(1) No conduct constitutes an offense unless it is a crime or violation under this Code or another statute of this State." Sub-section (3) exempts the criminal contempt powers of courts.

107 Whalen v. United States, 445 U.S. 684, 689 (1980).

108 See Esquivel-Quintana v. Lynch, 810 F.3d 1019, 1023 (6th Cir. 2016), cert. granted, 137 S. Ct. 368 (2016) proclaiming that "[...] legislatures, not executive officers, define crimes." 
The dominant narrative notwithstanding, some US scholars have expressed their concerns related to the mechanics and operation of allembracing blanket crimes, which not only 'paint with a broad brush' but also leave a portion of the task of filling securities crimes with contents to the SEC, prosecutors and courts deciding cases. Analyzing insider trading-related court decisions, for example, Baer warned in 2017 about "several of the drawbacks [of the securities criminal system] that arise when criminal laws become the product primary of cases and not statutes."109

One ought to add as well that the federal securities criminal laws share the fate, and many features of other federal criminal laws; including also the reasons why the system itself is being legitimately criticized. These should also be borne in mind when formulating the final verdict on the US securities criminal system; as it obviously bleeds from more wounds. In particular, what is referred to as 'federal criminal code' is a misnomer because " $t \mathrm{t}]$ here is actually no federal criminal 'code' worthy of the name. [...]. What the federal government has is a haphazard grab-bag of statutes accumulated over 200 years, rather than a comprehensive, thoughtful, and internally consistent system of criminal law." ${ }^{110}$

The "system" is legitimately criticized also for over-criminalization, overreach to areas traditional being in State competence, as well as repetition, overlaps, vagueness if not trivialization of criminal sanctions; ${ }^{111}$ defects some of which were hinted at above. The ultimate result being such a non-transparent criminal law in which it is impossible even to count the number of criminal offenses; as US scholars complain. ${ }^{112}$

\section{CONCLUSiON}

Indisputably, the above narrative is, and was meant, to be limited to showing why the scrutiny of the US securities crimes laws would make sense in Europe (and beyond), in particular through identifying and

109 Baer, M. H., 2017, Insider Trading's Legality Problem, Yale Law Journal Forum, Vol. 127, No. 2017-18, p. 129.

110 O'Sullivan, J., 2006, p. 643.

111 Ibid., p. 651 et seq.

112 As expressively stated by Smith in 2019: "Federal criminal statutes are not contained in any one volume of the U.S. Code, not even Title 18, the one volume specifically entitled 'Crimes and Criminal Procedure' but rather are scattered throughout almost fifty different volumes, without useful indexing and cross-references. In addition to being difficult to find, federal criminal statutes are often quite complex and multifaceted in structure, with a single provision creating an array of separately enforceable criminal prohibitions." Smith, S. F., 2019, Federalization's Folly, San Diego Law Review, Vol. 56, No. 1, p. 36. 
dissecting those underlying elements that make the system work. Importantly, as showed, the formula of success does not rest on a single element, but is rather the synergic output of a number of identifiable interlinked factors. What we called as blanket all-embracing crimes above being only one of them. These peculiar species of crimes, moreover, are relied on by US prosecutors to combat fraud on the markets in combination with general ones; as eloquently expressed by Judge Rakoff. Not much wisdom is therefore needed to realize that mere transition of even the most perfectly drafted statutory definitions, in isolation from its underpinnings, could hardly produce satisfactory results.

The above analysis is limited also in the sense that each of the elements tackled would require further scrutiny, similarly to many more questions deserving exploration and comparison of what European, and other developed systems could offer as functional equivalents. Virtually it lends itself to be formulated based on the above, for example, how the mutually-fruitful cooperation of the local financial supervisory agencies and prosecutorial offices could be developed in other countries? Or, whether the replication of the high deference to SEC's interpretations elsewhere should be considered? And ultimately whether efficient enforcement of securities crimes is possible without so radically changing the evidentiary standards as done in New York State; particularly in the age of online financial fraud dawning on all of us.

A fuller list of factors to be explored eventually would require scrutiny of rule of law issues as well, which so far have hardly been tackled comparatively specifically related to securities crimes and the linked criminal justice system. This would be more than desirable as the utility and applicability of all the remedies of the US, or any other develop system, are contingent on the existence of such a conducive socio-economic and legal environment that may not exist elsewhere. Suffice to point to the fact that, although obviously not all judges and prosecutors are top experts of securities laws in the US either, still the level of their knowledge on investing and all the other corollaries of capital markets is comparably significantly higher than in emerging economies. The problems sophisticated phenomena as 'regulatory capture'113 might create in the domain, and which

113 The exact meaning, the contours of, and consequently what qualifies as regulatory capture is debated. Posner defined it as "subversion of regulatory agencies by the firms they regulate $[. .$.$] ," meaning "that the regulated firms have [. .$.$] made war on the$ regulatory agency and won the war, turning the agency into their vassal." Posner, A. R. The Concept of Regulatory Capture - A Short Inglorious History, in: Carpenter, D., Moss, D. A., 2014, Preventing Regulatory Capture - Special Interest Influence and How to Limit It, Cambridge, at 49. 
could already being hotly debated in the US, ${ }^{114}$ might be completely foreign concepts in other jurisdictions.

All these considerations obviously would deserve attention as well, together with the utmost concerns generated by the most vicious enemy of the markets: corruption. And indeed, one cannot but agree that in countries in which financial supervisory agencies and prosecutorial offices are overwhelmed by corruption, are captured by politics or the affected industries, the intrinsic strengths of the above-discussed tools of US securities criminal system obviously cannot evolve to their fullest potentials (if at all). In such fortunate countries where that is not so, properly positioned all-embracing blanket securities crimes, supported by the less palpable elements of the criminal enforcement system canvassed above, however, could undoubtedly make a fundamental difference.

\section{BIBLIOGRAPHY}

1. Baer, M. H., 2017, Insider Trading's Legality Problem, Yale Law Journal Forum, Vol. 127, No. 2017-18.

2. Bazoian, Ph. K., 2012, The Ponzi Book: Unraveling Ponzi Schemes, New York, LexisNexis.

3. Bohlander, M., 2009, Principles of German Criminal Law, Hart Publishing, Oxford.

4. Brown, S. L., 2017, Mutual Funds and the Regulatory Capture of the SEC, University of Pennsylvania Journal of Business Law, Vol. 19, No. 3.

5. Brewer, M. K., Gough, O., Shah, N. S., 2011, Reconsidering Disclosure and Liability in the Transatlantic Capital Markets, DePaul Business \& Comparative Law Journal, Vol. 9, No. 2.

6. Brown, R. J. Jr., 1996, Of Brokers, Banks and the Case for Regulatory Intervention in Russian Securities Markets, Stanford Journal of International Law, Vol. 32, No. 2.

7. Brummer, C., 2015, Disruptive Technology and Securities Regulation, Fordham Law Review, Vol. 84, No. 3.

8. Buell, S. W., Griffin, L. K., 2012, On the Mental State of Consciousness of Wrongdoing, Law and Contemporary Problems, Vol. 75, No. 2.

9. Coffee, J. C. Jr., 1999, Privatization and Corporate Governance: The Lessons from Securities Market Failure, Journal of Corporation Law, Vol. 25, No. 1.

10. Coffee, J. C. Jr., Sale, H. A., 2009, Securities Regulation, New York, Foundation Press.

114 On the 'capture' of SEC by the mutual fund industry see Brown, S. L., 2017, Mutual funds and the regulatory capture of the SEC, University of Pennsylvania Journal of Business Law, Vol. 19, No. 3, pp. 701-750. 
11. Dymke, M. B., Walter, A., 2008, Insider Trading in Germany - Do Corporate Insiders Exploit Inside Information? BuR - Business Research Official Open Access Journal of $V H B$, Vol. 1, No. 2.

12. Diver, C. S., 1985, Statutory Interpretation in the Administrative State, University of Pennsylvania Law Review, Vol. 133, No. 3, p. 549.

13. Dix, E. G., Sharlot, M., 2008, Criminal Law - Cases and Materials, $6^{\text {th }}$ ed., St. Paul, Thomson-West.

14. Drumbl, M. A., 2017, The Two Illusions of All-Embracing Criminal Justice and Exclusively Extrajudicial Responses to Mass Atrocity, in: Bergsmo, M., (ed.), Abbreviated Civil Procedures for Core International Crimes, Torkel Opsahl Academic Publisher, Brussels, 2017.

15. Ernst, G. P., 2017, Blankettstrafgesetze under ihre Verfassungsrechlichen Grenzen [Blanket Laws and their Constitutional Limitations], Springer, Wiesbaden.

16. Falvey, J. J. Jr., Wolfman, M. A., 2002, The Criminal Provisions of Sarbanes-Oxley: A Tale of Sound and Fury, White-Collar Crime Reporter, Vol. 16, No. 11.

17. Frankel, T., 2012, The Ponzi Scheme Puzzle: A History and Analysis of Con Artists and Victims, Oxford University Press.

18. Garner, B. A., 2009, Black's Law Dictionary, $9^{\text {th }}$ DeLuxe ed., St. Paul, WestThomson.

19. Gordon, H. K., 2015, Enforcement Proceedings under New York's Martin Act, Practical L.J. - New York Litigation, Vol. 20, No. 26.

20. Gullifer, L., Payne, J., 2011, Corporate Finance Law - Principles and Policy, $1^{\text {st }}$ ed., Oxford, Hart Publishing.

21. Hazen, T. L., 1995, Treatise on the Law of Securities Regulation, $3^{\text {rd }}$ ed.

22. Jarvis, C., 2002, The Rise and Fall of the Pyramid Schemes in Albania, IMF, Washington D.C.

23. Joynston, N., 2020, Securities Fraud, American Criminal Law Review, Vol. 57, No. 3.

24. Kaleb, Z., 2014, Kaznena djela protiv tržišta kapitala i vrijednosnih papira prema novome kaznenom zakonu [Crimes against Capital- and Securities Markets According to the New Criminal Act], Zagreb, Policija i sigurnost, Vol. 23, No. 1.

25. Kostić, J., 2018, Izazovi harmonizacije krivičnopravne zaštite tržišta kapitala sa pravom Evropske unije - Primer italijanskog zakonodavstva [The Challenges of the Harmonization of Penal Protection of Capital Markets According with the Law of the European Union - The Case of Italian Law], Strani pravni život, Vol. 62, No. 2.

26. Kostić, J., Trošić, S. J., (In)adequate criminal protection of the capital market in the Republic of Serbia, in: Petrašević, T., Duić, D., (eds.), 2020, Eclic 4, EU and Comparative Law Issues and Challenges, International Scientific Conference EU 2020 - Lessons from the past and solutions for the future, Osijek, September 1011, 2020 (Publ. Josip Juraj Strossmayer Law School, Osijek, Croatia).

27. Mathews, A. F., 1971, Criminal prosecutions under the federal securities laws and related statutes: The nature and development of sec criminal cases, George Washington Law Review, Vol. 39, No. 5.

28. Merrill, T. W., Hickman, K. E., 2001, Chevron's Domain, Georgetown Law Journal, Vol. 89, No. 4. 
29. Morrissey, D. J., 2019, The EU's Struggles with Collective Action for Securities Fraud: An American Perspective, Texas A\&M Law Review, Vol. 7, No. 1.

30. Nichols, Ch., 2011, Addressing Inept SEC Enforcement Efforts: Lessons from Madoff, the Hedge Fund Industry, and Title IV of the Dodd-Frank act for U.S. and Global Financial Systems, Northwestern Journal of International Law \& Business, Vol. 31, No. 2011.

31. O’Sullivan, J., 2006, The Federal Criminal 'Code' Is a Disgrace: Obstruction Statutes as Case Study, Journal of Criminal Law \& Criminology, Vol. 96, No. 2.

32. Pravna enciklopedija, volume one, 1989, Belgrade, Savremena administracija.

33. Posner, A. R., The Concept of Regulatory Capture - A Short Inglorious History, in: Carpenter, D., Moss, D. A., 2014, Preventing Regulatory Capture - Special Interest Influence and How to Limit It, Cambridge.

34. Rakoff, J. S., 1980, The Federal Mail Fraud Statute (Part I), Duquesne Law Review, Vol. 18 , No. 4.

35. Remington, J., 1954, Criminal Law Revision Codification vs. Piecemeal Amendment, Nebraska Law Review, Vol. 33, No. 3.

36. Richardson, W. P., 1928, The Law of Evidence, $3^{\text {rd }}$ ed., Brooklyn Law School.

37. Robinson, P. H., 2005, Fair Notice and Fair Adjudication: Two Kinds of Legality, University of Pennsylvania Law Review, Vol. 154, No. 2.

38. Robinson, P. H., Dubber, M. D., 2007, The American Model Penal Code: A Brief Overview, New Criminal Law Review, Vol. 10, No. 3.

39. Sachs, M. V., 2001, Harmonizing Civil and Criminal Enforcement of Federal Regulatory Statutes: the Case of the Securities Exchange Act of 1934, University of Illinois Law Review, Vol. 2001, No. 4.

40. Sinha, P., 1989, Parallel civil and criminal proceedings, American Criminal Law Review, Vol. 26, No. 3.

41. Smith, S. F., 2019, Federalization's Folly, San Diego Law Review, Vol. 56, No. 1.

42. Tajti, T., 2019, Pyramid and Ponzi Schemes and the Price of Inadequate Regulatory Responses: A Comparative Account of the Diverging Regulatory Responses, Business \& Bankruptcy Law Journal, Vol. 5, No. 2001.

43. Tajti, T., 2021, Are Some Classes of Consumer-Investors of Collapsed Pyramid and Ponzi Schemes Vulnerable? in: Stănescu, C-G., Gikay, A. A. (eds.), Discrimination, Vulnerable Consumers and Financial Inclusion - Fair Access to Financial Services and the Law, London-New York, Routledge.

44. Turanjanin, V., 2017, Privredna krivična dela iz sporednog krivičnog zakonodavstva [Economic Crimes in Blanket Crimes Statutes], in: Stevanović, I., Čotović, V., Privredna krivična dela, Belgrade, Institut za uporedno pravo - Institute za kriminološka i sociološka istraživanja.

45. Wechsler, H., 1952, The Challenge of a Model Penal Code, Harvard Law Review, Vol. 65, No. 7.

46. Wiener, I. A., 2001, A Büntető Törvénykönyv Szerkezete - A szakmai bűncselekmények és az értelmező rendelkezések (The Structure of the Criminal Code - Professional Crimes and the Interpretative Provisions), Büntetőjogi Kodifikáció, Vol. 2001, No. 1. 


\section{Legislative SOURCES}

1. Act on Crimes against Capital Markets (Zakon o kaznenim djelima protiv tržišta kapitala, Narodne novine, No. 152-08, 2008) (Croatia).

2. Act of year 2001 No. CXX on Capital Market (2001. évi CXX. törvény a tőkepiacról), (Hungary).

3. Capital Market Act “Kapitalmarktgesetz" (BGBI. I Nr. 62/2019) (Austria).

4. Capital Market Act (Official Gazette of RS, No 31/2011, 112/2015, 108/2016 and 9/2020) (Serbia).

5. Clayton Antitrust Act of 1914 (United States, federal).

6. Communication from the Commission to the European Parliament, the European Council, the Council, the European Central Bank, the European Economic and Social Committee and the Committee of the Regions Capital Markets Union: Progress on Building a Single Market for Capital for a Strong Economic and Monetary Union (Brussels, 15 March 2019), (European Union).

7. Criminal Code ("Bundesgesetz vom 23. Jänner 1974 über die mit gerichtlicher Strafe bedrohten Handlungen” (Strafgesetzbuch - StGB) StF: BGBl. Nr. 60/1974 as amended. (Austria).

8. Criminal Act ("Kazneni zakon", Narodne novine, No. 125-11 as amended), (Croatia).

9. Criminal Code ("Strafgesetzbuch in der Fassung der Bekanntmachung vom 13. November 1998 (BGBl. I S. 3322)”), (Germany).

10. Criminal Code 1997 (“Ustawa z dnia 6 czerwca 1997 r. - Kodeks karny” as amended), (Poland).

11. Criminal Code ("Krivični zakonik", Official Gazette of RS, No. 85/2005 as amended), (Serbia).

12. Criminal Code ("Organic Law", No. 10/1995, of 23 November, of the Criminal Code, "Ley Orgánica 10/1995, de 23 de noviembre, del Código Penal”), (Spain).

13. Directive 2014/57/EU of the European Parliament and of the Council of 16 April 2014 on criminal sanctions for market abuse (market abuse directive).

14. Dodd-Frank Wall Street Reform and Consumer Protection Acts (2010), (United States, federal).

15. Financial Services and Markets Act 2000 (2000 c. 8), as amended by Section 92, Part 7, of the Financial Services Act 2012 (2012 c. 21), (United Kingdom).

16. Investment Advisers Act of 1940 (United States).

17. Investment Company Act of 1940 (United States).

18. Law on Open-Ended Investment Funds subject to Public Offering (Official Gazette of RS, No. 73/2019), (Serbia).

19. Law on Takeovers of Joint Stock Companies (Official Gazette of RS, Nos. 46/2006, 107/2009, 99/2011 and 108/2016), (Serbia).

20. Market Abuse Regulation 569/2014 (L 173/1), (European Union).

21. Model Penal Code (American Law Institute, Washington, D.C., 1962) (https:// www.ali.org/publications/show/model-penal-code/), (United States). 
22. New York General Business Law, art. 23-A, ss. 352-353 (United States).

23. Public Utility Holding Act of 1935 (United States, federal).

24. Sarbanes and Oxley Act (2002), (United States, federal).

25. Securities Act (R.S.O. 1990, c.S.5), (Ontario, Canada).

26. Securities Act 1933 (United States, federal).

27. Securities Exchange Act 1934 (United States, federal).

28. Securities Trading Act (1994) (“Gesetz über den Wertpapierhandel”) (BGBI. I S. 2708, last amended on 12 Sept. 2020), (Germany).

29. Sherman Antitrust Act of 1890 (United States, federal).

30. Trust Indenture Act of 1939 (United States, federal).

\section{Case Law}

1. Archer et al. v. SEC (1943).

2. Board of Trade of the City of Chicago v. Securities and Exchange Commission, 923 F.2d 1270 ( $7^{\text {th }}$ Cir., 1991).

3. Chevron U.S.A., Inc. v. Natural Resources Defense (104 S.Ct. 2778 (1984)).

4. Chiarella v. United States (445 U.S. 222, 100 S.Ct. 1108, 63 L.Ed.2d 348, 1997).

5. Christensen v. Harris County (120 S.Ct. 1655, 2000).

6. Dirks v. SEC (463 U.S. 646, 103 S.C. 3255, 77 L.Ed.2d 911).

7. EEOC v. Arabian Am. Oil Co., 499 U.S. 244, 259 (1991).

8. Esquivel-Quintana v. Lynch, 810 F.3d 1019, 1023 (6th Cir. 2016), cert. granted, 137 S. Ct. 368 (2016).

9. Holland v. U.S., 348 U.S. 121, 40 (1954).

10. Hughes v. SEC, 174 F.2d 969.

11. People v. Rodriguez, 957 N.E. 2d 1133 (N.Y. 2011).

12. People v. Sala, 695 N.H.S. 2d 169 (App. Div. 1999) [New York State].

13. R v. McQuoid, Southwark Crown Court, 27 March 2009 (unreported), [United Kingdom].

14. SEC v. C.M. Joiner Leasing Corporation, 320 U.S. 344 (1943).

15. SEC v. Dresser Industries, 628 F.2d at 1376.

16. SEC v. Sloan, 98 S. Ct. 1702 (1978).

17. Tellabs, Inc. v. Makor Issues \& Rights, Ltd., 551 U.S. 308, 127 S.Ct. 2499, 168 L.Ed.2d 179.

18. United States v. Dixon, 536 F.2d 1388 (2nd Cir., 1976).

19. United States v. Kluger, 722 F.3d 549 (3d Cir. 2013).

20. United States v. Lewis, 594 F.3d 1270 (10th Cir. 2010).

21. United States v. O’Hagan (521 U.S. 642, 117 S.Ct. 2199, 138 L.Ed.2d 724).

22. Whalen v. United States, 445 U.S. 684, 689 (1980). 


\section{INTERNET SOURCES}

1. Consolidated Laws of New York, Penal, Part 2, Title E (Sentences), Article 70(2) (e) - Sentence of imprisonment for felony, (https://www.nysenate.gov/legislation/ laws/PEN/70.00).

2. McTamaney, R. A., 2003, New York's Martin Act: Expanding Enforcement in an Era of Federal Securities Regulation, Washington Legal Foundation, (https://www. clm.com/docs/2-28-03mctamaney.lb.pdf).

3. Norges Bank - Investment Management, (https://www.nbim.no/).

4. Norwegian Investment Fund, (https://www.norfund.no/).

5. Private Equity firm 'iEurope Private Capital', (http://ieurope.com/).

6. Ponzi Book blog (Kathy Bazoian Phelps), www.theponzibook.com).

7. Ponzitracker (Jordan Maglich), (https://www.ponzitracker.com).

\section{OTher Sources}

1. ABA Task Force on Federalization of Criminal Law, 'TASK FORCE REPORT' (1998).

2. Burgess, K., Masters, B. (13 May 2010) A Bigger Bite, Financial Times (London, $\mathrm{UK})$.

\section{ŠTA ČINI SISTEM KRIVIČNOPRAVNE ZAŠTITE INTEGRITETA TRŽIŠTA KAPITALA U SJEDINJENIM AMERIČKIM DRŽAVAMA EFIKASNIM? BLANKETNA KRIVIČNA DELA PROTIV INTEGRITETA TRŽIŠTA KAPITALA I SISTEM KRIVIČNOG GONJENJA}

Tibor Tajti (Thaythy)

\section{APSTRAKT}

Članak istražuje ključne faktore koji čine krivičnopravnu zaštitu tržišta kapitala Sjedinjenih Američkih Država (SAD) efikasnom, imajući u vidu da je ta zaštita integralni deo tržišta kapitala i regulatornog sistema hartija od vrednosti. U članku se analiziraju uloga i karakteristike blanketnih krivičnih dela protiv tržišta kapitala predviđena u saveznim zakonima o tržištu kapitala, kao i njihova povezanost sa opštim krivičnim delima. Osim toga, predmet analize su i bliska saradnja Komisije za berzu hartija od vrednosti (SEC) i tužilaštava, važeći standardi u pogledu postupka dokazivanja, kao i osnovne ideje koje čine suštinu zakona o tržištu kapitala. Bogato američko iskustvo trebalo bi da bude poučno ne samo državama 
članicama Evropske unije (EU) koje teže da podstaknu dalji razvoj već razvijenijih tržišta kapitala, nego i onim državama koje nastoje da pristupe EU (npr. Srbija) ili da razviju tržište kapitala, što nije moguće postići bez efikasnog gonjenja krivičnih dela protiv tržišta kapitala.

Ključne reči: tržišta kapitala, blanketna krivična dela protiv tržišta kapitala, dokazivanje mens rea, posredni dokazi, nulla crimen sine lege.

Article History:

Received: 1 February 2021

Accepted: 11 June 2021 